is down to a number of factors, including government policies and corporate efforts to clean up beef and soya-bean supply chains. Academics are still dissecting out cause and effect, trying to understand what worked where and how to help other countries to follow suit.

The first major factor is that in 2004 the Brazilian government decided to take the issue seriously. Harnessing its satellite-monitoring system, the government mounted sustained enforcement campaigns in areas where deforestation was rampant. It worked to root out corruption within the ranks of its environmental law enforcement agency by, for example, rotating teams among regions to prevent the kind of long-term relationships that enable bribery. It also designated new public land for permanent protection, engaged banks that provide agricultural loans, and increased pressure on local governments, which stepped up their own campaigns.

But the government did not act alone. Capitalizing on publicly available satellite data, environmental groups put a spotlight on the international corporations that trade in beef and soya beans. Most of the major players in both industries buckled under public pressure and signed agreements to halt purchases of the products from recently cleared land; new research suggests that these moratoria are changing the way landowners do business. Industrial-scale deforestation in the Amazon has been driven by global demand for protein, be it beef or soya beans, which often serve as a feedstock for chicken and pork. But globalization can also be a force for good when consumers and businesses raise their standards.

Brazil has created a portfolio of tools that other countries can study as they seek to minimize deforestation. But what comes next is less clear. No one has identified a simple recipe for sustainable rural development, and chopping down forests remains a profitable affair among criminal land speculators. Solving these problems will require extra effort as well as money, and this at a time when Brazil is struggling to stave off outright recession.

Global policy-makers created a mechanism under the United Nations Framework Convention on Climate Change to help with such efforts. Dubbed REDD, for reducing emissions from deforestation and forest degradation, this pay-for-performance system is based on the carbon that is locked up in trees. Developing countries that document
“Brazil's experience shows the potential for rapid progress." reduced deforestation and thus carbon dioxide emissions - or an expansion of forests - are eligible for payments from wealthy countries. Norway has already committed US $\$ 1$ billion to Brazil, which is dispersing the money for a range of government initiatives as well as research and policy experiments.

The challenge internationally is to ramp up funding for forest conservation and restoration, which is the easiest way to pull large amounts of carbon dioxide out of the atmosphere. Countries have already committed more than $\$ 7.5$ billion to the cause, and many governments and companies have made forest pledges. At a UN summit last September, a host of countries joined businesses, environmental groups and indigenous organizations in signing the New York Declaration on Forests, which calls for a halving of deforestation by 2020 and to end it by 2030 . The document also calls for the restoration of 350 million hectares of forests and other landscapes globally by 2030 . These are admirable goals, but further investments, particularly from the private sector, are needed if the world is to meet them.

Brazil is still writing its story in the Amazon, but its experience shows the potential for rapid progress. It also holds lessons for activists, businesses and governments: foremost among them is that it takes all three to tango. It's a complicated dance, but one the world must learn.

\section{Walking 2.0}

\section{A passive device that augments calf muscles improves on natural selection's best effort.}

\footnotetext{
$\mathrm{G}$
} iven that scientists can probe the secrets of matter and gaze into the depths of the cosmos, it is a wonder that we still have anything to learn about something as seemingly simple as the way we walk. Yet how and why humans evolved to walk on two legs a feat that many take for granted - remains an active field of research. Not least because no one has yet managed to build a humanoid robot with the natural grace and poise of, say, someone walking to the post office, let alone with that of an Olympic athlete or catwalk model.

Armchair scenarios to explain how humans became bipedal turn up occasionally as submissions to this journal. Yet most fail to account for the manifold adaptations that humans require to assume the posture that most toddlers do without thinking.

Every part of our bodies is adapted to bipedality. Every nerve is tuned, every muscle responsive to the merest twitch of feedback required to keep something so intrinsically unstable vertical and in motion, and all without conscious thought.

This instability is key: the more unstable the object, the more manoeuvrable it is. Imagine the control systems that would be needed for a child to fly a modern fighter jet, and you begin to grasp the scale of the problem.

This explains why Nature is proud to publish a report this week that some readers might at first glance dismiss as quotidian engineering rather than pure science (S. H. Collins et al. Nature http://dx.doi. org/10.1038/nature14288; 2015). The authors have created a mechanical boot fitted with a disarmingly simple spring-loaded device that augments the force of the wearer's calf muscles, reducing the metabolic cost of walking by about 7\%.

That might not sound like much, until one considers two remarkable things. First, the device is completely passive - it has no batteries and consumes no external power. Second, given that we assume that adaptations produced by evolution tend to the optimal, it is amazing that an improvement of this amount is even possible. Natural selection has honed human walking over millions of years, and yet there is still substantial room for improvement. Despite the way the phrase is sometimes used, natural selection is not a motive force for progressive improvement towards inevitable perfection, but an endless series of compromises as organisms adapt to new circumstances given the anatomies they have.

Humans come from a long line of creatures that mostly walked on all fours, supported by a horizontal backbone with vertebrae held under tension. Making the backbone vertical puts compressive loads on vertebrae, which can have painful consequences; lower back pain is the leading cause of worker absenteeism after the common cold, accounting for $15 \%$ of sick leaves and hundreds of millions of lost work days annually. Matters are even worse for pregnant women, and there is evidence that the spine has evolved further fixes to accommodate the enormous and sudden burden of carrying a fetus (K. K. Whitcome et al. Nature 450, 1075-1078; 2007). So perhaps it is no surprise that there are still energy savings to be made, given that humans are products of evolution and not of conscious design. If we were going to be truly efficient at getting around, we would have evolved wheels.

A passive exoskeleton for the lower leg is a far cry from the commuter jet packs imagined in 1950s science fiction. Still, if one is inclined to dismiss a 7\% saving as modest, one might easily imagine circumstances in which such a margin could mean all the difference between immo- $\rightarrow$ NATURE.COM To comment online, click on Editorials at: go.nature.com/xhunqv bility and freedom. A passive device such as this might be just enough, say, to help a person with impaired mobility to get out of the house. A person for whom a trip to the post office might at present be as out of reach as a jet pack. 